\title{
Vaginal Large Cell Neuroendocrine
} Carcinoma

National Cancer Institute

\section{Source}

National Cancer Institute. Vaginal Large Cell Neuroendocrine Carcinoma. NCI Thesaurus.

Code C128075.

A rare, aggressive neuroendocrine carcinoma that arises from the vagina and is

characterized by the presence of malignant cells with abundant cytoplasm, large nuclei, and prominent nucleoli. 